\title{
Effect of red chilli powder on DNA content of gastric aspirates
}

\author{
H. G. DESAI, K. VENUGOPAlAN, AND F. P. ANTIA \\ From the Pai Department of Gastroenterology, B.Y.L. Nair Charitable Hospital, Bombay, India
}

SUMmARY The intragastric infusion of red chilli powder in dosage of 1.6 and $0.8 \mathrm{~g} / \mathrm{hr}$ caused a marked increase in the DNA content of the gastric aspirate compared with basal values for DNA. This observation suggests a rapid and marked exfoliation of gastric surface epithelial cells in human subjects given red chilli powder.

The surface epithelial cells of human gastric mucosa are continuously exfoliated. Since the deoxyribonucleic acid (DNA) content in each of these somatic nuclei is identical, the measurement of the DNA content in gastric aspirate over a fixed period of time indicates the rate at which gastric surface epithelial cells are extruded (Croft, Pollock, and Coghill, 1966). Drugs such as aspirin and phenylbutazone were shown to cause increased exfoliation of surface epithelial cells in dogs (Max and Menguy, 1970).

Spices have been blamed in the aetiology of gastritis and peptic ulcer for many years but scanty data are available showing their effect on human gastric mucosa (Sanchez-Palomera 1961a, 1951b; Schneider, De Luca, and Gray, 1956; MacDonald, Anderson, and Hashimoto, 1967). Since the average consumption of red chilli powder in our Indian subjects is about $3.0 \mathrm{~g} /$ day (unpublished observation), a study showing its effect on the rate of exfoliation of surface epithelial epithelial cells of human gastric mucosa may be of some importance. The aim of this study has been to measure the DNA content in gastric aspirate in the basal state and after infusion of red chilli powder into the stomach.

\section{Materials and Methods}

Red chillies were ground into an extremely fine powder.

A polythene tube was fixed to 16 Fr Levine tube so that its terminal end was $15 \mathrm{~cm}$ proximal to the distal end of the Levine tube. This double-lumen tube was passed in stomach of the fasting subject so that the distal end of the Levine tube was at about Received for publication 29 August 1973.
$55 \mathrm{~cm}$ distance from the incisor teeth. The tip of the Levine tube was considered to be located in the most dependent portion of the stomach when at least $450 \mathrm{ml}$ of $500 \mathrm{ml}$ of normal saline injected through the polythene tube was aspirated through the Levine tube. The fasting contents and this gastric washout were discarded.

During one hour, $500 \mathrm{ml}$ of normal saline was slowly infused through the polythene tube and the gastric aspirate collected through the Levine tube (B). The measured quantity of red chilli powder was added to $500 \mathrm{ml}$ of normal saline and the same was slowly infused through the polythene tube for the next hour and the gastric aspirate was collected (S). The DNA content in the B and S samples was measured with diphenylamine reagent by the method described by Croft and Lubran (1965). The gastric aspirates were collected in bottles containing $25 \mathrm{ml}$ of ethylene diamine tetraacetic acid (EDTA) to prevent destruction by deoxyribonucleases and kept in ice. For each $100 \mathrm{ml}$ of gastric aspirate, $0 \cdot 15 \mathrm{ml}$ of $30 \%$ bovine albumin and $10 \mathrm{ml}$ of $50 \%$ trichloracetic acid (TCA) were added to precipitate DNA and the samples stored at -16 to $-20^{\circ} \mathrm{C}$ for a minimum period of three days. Aftercentrifugingat $4{ }^{\circ} \mathrm{C}$, the deposit was mixed with $50 \mathrm{ml}$ of $5 \%$ TCA and centrifuged again; to the deposit $4 \mathrm{ml}$ of $5 \%$ TCA was added and kept in a water bath at $90^{\circ} \mathrm{C}$ for $15 \mathrm{~min}$. After cooling and centrifuging, the last step was repeated. The supernatant was stored at -16 to $-20^{\circ} \mathrm{C}$ for one day. The hydrolysate was thawed and centrifuged at $4^{\circ} \mathrm{C}$ and the volume of the supernatant was noted. To $2 \mathrm{ml}$ of the final supernatant, $0.2 \mathrm{ml}$ of perchloric acid and $2 \mathrm{ml}$ of $2 \%$ diphenylamine reagent were added and stored at $6^{\circ}$ to $13^{\circ} \mathrm{C}$ for at 
least 48 hours. The blue colour that developed was read at wavelength $600 \mathrm{~m} \mu$. The DNA values of gastric aspirates were obtained by comparison with a DNA standard solution (kept with each sample) prepared from highly polymerized calf thymus DNA (Sigma). The values of atoms of phosphorus in DNA were obtained from the formula $0.4 \mathrm{mg}$ DNA $=0.836 \mu \mathrm{g}$ DNA-P. The final values are given as ng atoms DNA-P/min. The statistical analysis was done using the paired $t$ test.

\section{Subjects}

The control subjects and patients with duodenal ulcer (in remission) and chronic gastritis were studied. The diagnosis of duodenal ulcer was based on radiological confirmation and of chronic gastritis on gastric biopsy. The gastric biopsy was obtained from the fundus or body of the stomach with a Crosby-Kugler capsule.

\section{Results}

DNA CONTENT OF RED CHILLI POWDER

It was initially confirmed that the red chilli powder did not contain any DNA.

\section{REPRODUCIBILITY OF RESULTS}

In 10 subjects, DNA content in two 60 -min basal collections was measured and the values were $25 \cdot 2,25 \cdot 2 ; 16 \cdot 6,17 \cdot 7 ; 32 \cdot 5,32 \cdot 5 ; 26 \cdot 8,27 \cdot 9 ; 18 \cdot 3$, $18 \cdot 0 ; 14 \cdot 3,14 \cdot 3 ; 5.9,6 \cdot 5 ; 10 \cdot 9,10 \cdot 7 ; 22 \cdot 5,21 \cdot 7$; $9 \cdot 4,9 \cdot 2 \mathrm{ng}$ atoms DNA $-\mathrm{P} / \mathrm{min}$.

\section{EFFECT OF RED CHILLI POWDER}

\section{Intragastric infusion of $1.6 \mathrm{~g} / \mathrm{hr}$ (table I)}

There were six control subjects and three patients with duodenal ulcer. The mean and SEM of the

\begin{tabular}{lll}
\hline No. & \multicolumn{2}{l}{ DNA-P (ng atoms/min) } \\
\cline { 2 - 3 } & Basal & With Red Chilli \\
\hline 1 & $10 \cdot 8$ & $13 \cdot 6$ \\
2 & $12 \cdot 5$ & $22 \cdot 3$ \\
3 & 13.9 & $14 \cdot 3$ \\
4 & $16 \cdot 0$ & $37 \cdot 9$ \\
5 & $31 \cdot 7$ & $51 \cdot 5$ \\
6 & $23 \cdot 0$ & $37 \cdot 9$ \\
7 & $15 \cdot 33$ & $19 \cdot 5$ \\
8 & $23 \cdot 0$ & $35 \cdot 5$ \\
9 & $12 \cdot 7$ & 16.4 \\
\hline
\end{tabular}

Table I The effect of intragastric infusion of red chilli powder $(1 \cdot 6 \mathrm{~g} / \mathrm{hr})$ on DNA content of gastric aspirate

Mean and SEM of differences on paired $t$ test $10.0 \pm 2 \cdot 45, t 3 \cdot 85$, $\mathbf{P}<0.01$

11-6 control subjects, 7-9 duodenal ulcer increase of DNA in gastric aspirate after intragastric infusion of red chilli powder were 10.0 \pm 2.45 ng atoms DNA $-\mathrm{P} / \mathrm{min}$ in nine subjects; the differences were highly significant $(t=3.85 ; P<0.01)$.

\section{Intragastric infusion of $0.8 \mathrm{~g} / \mathrm{hr}$ (table II)}

There were 11 control subjects, four with duodenal ulcer and one with chronic gastritis. The mean and SEM of the increase of DNA in gastric aspirate after intragastric infusion of red chilli powder were $7.63 \pm 1.95 \mathrm{ng}$ atoms DNA-P/min in 16 subjects; the differences were highly significant $(t=3 \cdot 7$, $P<0.01)$. In 14 out of 16 subjects, an increase in the DNA content of gastric aspirate was observed after the infusion of red chilli powder.

\begin{tabular}{lll}
\hline No. & \multicolumn{2}{l}{$D N A-P($ ng atoms/min $)$} \\
\cline { 2 - 3 } & Basal & With Red Chilli \\
\hline 1 & $13 \cdot 6$ & $37 \cdot 9$ \\
2 & $24 \cdot 4$ & $34 \cdot 8$ \\
3 & $20 \cdot 9$ & $37 \cdot 6$ \\
4 & $26 \cdot 5$ & $24 \cdot 4$ \\
5 & $13 \cdot 9$ & $24 \cdot 4$ \\
6 & $28 \cdot 9$ & $33 \cdot 4$ \\
7 & $7 \cdot 0$ & $26 \cdot 5$ \\
8 & $23 \cdot 3$ & $24 \cdot 4$ \\
9 & $34 \cdot 8$ & $42 \cdot 8$ \\
10 & $19 \cdot 5$ & $29 \cdot 6$ \\
11 & $24 \cdot 0$ & $18 \cdot 1$ \\
12 & $24 \cdot 7$ & $32 \cdot 4$ \\
13 & $12 \cdot 9$ & $16 \cdot 7$ \\
14 & $49 \cdot 8$ & $52 \cdot 2$ \\
15 & $13 \cdot 8$ & $14 \cdot 6$ \\
16 & $27 \cdot 1$ & $37 \cdot 9$ \\
\hline
\end{tabular}

Table II Effect of intragastric infusion of red chilli powder $(0.8 \mathrm{~g} / \mathrm{hr})$ on DNA content of gastric aspirate

Mean and SEM of differences on paired $t$ test: $7.63 \pm 1.95, t$ 3.7, $\mathbf{P}<0.01$

${ }^{11-11}$ control subjects, 12-15 duodenal ulcer, 16 chronic gastritis

\section{Discussion}

The effect of red chilli powder or its active principle capsaicin on the mucosa of the palate or stomach of rat (Sirsat and Khanolkar 1960), dog, and human subject has been reported. The administration of spices in the stomach did not appreciably alter acid or pepsin secretion in human subjects (SanchezPalomera, 1951a; Pimparkar, Donde, Bhiwankar, and Mehta, 1972). Following the instillation of spices into the stomach macroscopic lesions such as oedema, congestion, or acute erosions were observed in a few patients on gastroscopy examination (Schneider et al, 1956). A marked increase in the number of mitotic figures and an appreciable alteration in surface epithelial cells in gastric antral 
biopsy from human subjects following the ingestion of certain pickles has also been described (MacDonald et al, 1967). The conclusion of these studies was that the spices have an 'irritative action' on human gastric mucosa.

The results of the present study showed that the red chilli powder, widely consumed by subjects from India, causes a rapid and increased exfoliation of gastric surface epithelial cells in human subjects. This observation is similar to that reported in a study showing the effect of aspirin on human gastric mucosa (Croft, 1963). The acute gastric erosion, causing haematemesis in man, following the ingestion of aspirin was explained on the basis of far greater exfoliation of surface epithelial cells than the capacity of the gastric mucosa toregenerate and replace the loss. Our observation suggests that the acute gastric erosion observed during gastroscopy (Schneider et al, 1956) following instillation of spices into the human stomach probably occurs by a similar mechanism. In patients with haematemesis or melaena of unknown aetiology, the possibility of a heavily spiced diet causing acute gastric erosion should be considered, especially in the tropics.

Substances such as aspirin causing increased exfoliation of gastric surface epithelial cells are known to break the gastric mucosal barrier which normally prevents a free reflux of hydrogen ions from gastric lumen to gastric mucosa (Davenport, 1964; Overholt and Pollard, 1968). Since red chilli powder also caused a similar increased exfoliation of gastric epithelial cells, the failure of red chillies to increase acid secretion in previous studies (SanchezPalomera 1951a; Pimparkar et al, 1972) may be due to increased reflux of secreted hydrogen ions from lumen to mucosa.

The work was completed with a grant from B.Y.L. Nair Charitable Hospital Research Society.

\section{References}

Croft, D. N. (1963). Aspirin and the exfoliation of gastric epithelial cells: cytological and biochemical observations. Brit. med. J., 2, 897-901.

Croft, D. N., and Lubran, M. (1965). The estimation of deoxyribonucleic acid in the presence of sialic acid: application to analysis of human gastric washings. Biochem. J., 95, 612-620.

Croft, D. N., Pollock, D. J., and Coghill, N. F. (1966). Cell loss from human gastric mucosa measured by the estimation of deoxyribonucleic acid (DNA) in gastric washings. Gut, 7, 333-343.

Davenport, H. W. (1964). Gastric mucosal injury by fatty and acetylsalicylic acids. Gastroenterology, 46, 245-253.

MacDonald, W. C., Anderson, F. H., and Hashimoto, S. (1967). Histological effect of certain pickles on the human gastric mucosa: a preliminary report. Canad. med. Ass. J.,96,15211525.

Max, M., and Menguy, R. (1970). Influence of adrenocorticotropin, cortisone, aspirin and phenylbutazone on the rate of exfoliation and the rate of renewal of gastric mucosal cells. Gastroenterology, 58, 329-336.

Overholt, B. F., and Pollard, H. M. (1968). Acid diffusion into the human gastric mucosa. Gastroenterology, 54, 182-189.

Pimparkar, B. D., Donde, U. M., Bhiwankar, N. T., and Mehta, J. M. (1972). Effects of commonly used spices on human gastric secretion. J. Ass. Phycns. India, 20, 901-910.

Sanchez-Palomera, E. (1951a). I. The action of spices on the acid gastric secretion, on the appetite and on the caloric intake. Gastroenterology, 18, 254-268.

Sanchez-Palomera, E. (1951b). Concept of the mucous barrier and its significance II changes in the gastric mucosa produced by the local actions of spices and other irritative agents. Gastroenterology, 18, 269-286.

Schneider, M. A., DeLuca, V., Jr., and Gray, S. J. (1956). The effect of spices ingestion upon the stomach. Amer. J. Gastroent., 26, $722-732$.

Sirsat, S. M., and Khanolkar, V. R. (1960). Submucous fibrosis of the palate in diet-preconditioned wistar rats. Arch. Path., 70, 171-179. 